\title{
Serebrovasküler Olay Geçiren Bir Olgunun Henderson Hemşirelik Modeli'ne Göre Değerlendirilmesi: Olgu Sunumu
}

\section{Assessment of a Case with Cerebrovascular Event According to Henderson's Model of Nursing: Case Report}

\author{
Funda Erol ${ }^{1}$, Fatma Tanrıkulu ${ }^{1}$, Yurdanur Dikmen ${ }^{1}$
}

1 Sakarya Üniversitesi Sağlık Yüksekokulu Hemşirelik Esasları Anabilim Dalı

\section{öz}

Hemşirelik disiplini kuram, araştırma ve uygulama olmak üzere üç temel öğeden oluşmakta ve bu öğeler karşılıklı etkileşim içinde hemşirelik biliminin gelişimine katkı vermektedir. Dolayısıyla hemşirelik, insanı sağıık ve hastalıktaki konumu ile anlamaya çalışan ve gereksinimlerine odaklanan bir sağlık disiplinidir. Profesyonel bir disiplinin temel amacl, mesleğin uygulamalarında kullanılabilecek bilimsel bilgi içeriğini oluşturmak ve geliştirmektir. Hemşireliğe özgü bilginin geliştirilme yollarından biri, hemşirelik modellerinin bakımda kullanımı ve araştırmalarla test edilmesidir. Ancak literatürde hemşirelik modellerini temel almadan yalnızca hemşirelik sürecini kullanmanın, bakım uygulamalarını açıklamakta yetersiz kaldığı ve uygulamaları mekanik bir iş haline getirdiği belirtilmektedir. Serebrovasküler olay (SVO); iyi bir gözlem, sürekli değerlendirme ve kapsamlı bakım gerektiren bir hastalıktır. Sağlıklı yaşam biçimi alışkanlıkları, uygun tedavi ve iyi bir hemşirelik bakımıyla SVO'da değiştirilebilir risk faktörleri elimine edilebilir ve hastalık sonrası gelişebilecek komplikasyonlar önlenebilir. $\mathrm{Bu}$ makalede, SVO geçiren hastalarda Henderson Hemşirelik Modeli kullanılarak hemşirelerin teorileri anlama ve bakımda kullanma sınırlılıklarının çözümüne katkı sağlayabilecek bir örnek oluşturulması amaçlanmıştır. Aynı zamanda elde edilen yeni bilgi, hemşirelerin bu hasta grubunu daha iyi anlamasına ve bakıma yansıtılarak hastaların yaşam kalitelerinin yükseltilmesine katkı sağlayabilir.

Anahtar Kelimeler: Hemşirelik Bakımı, Serebrovasküler olay, Herderson Hemşirelik Modeli

\section{ABSTRACT}

The discipline of nursing consists of 3 basic elements as the theory, the research and the practice. These elements, in interaction with each other contribute to the development of the science of nursing. Thus, nursing is a discipline of health which aims to comprehend the situation of human both in disease and health and focuses on its needs. Fundamental purpose of a professional discipline is forming and enhancing the content of scientific knowledge which can be used in the practice of the profession. One of the ways of enhancing the knowledge proper to nursing is the utilization of nursing models in care and testing them in the research. However, it is stated in literature that implementing nursing process without taking a nursing model as a basis fails to clarify the care practices and turns them into mechanical tasks. Cerebrovascular Event (CVE) is a disease which demands a good observation, a continous assessment and a comprehensive care. In CVE, with the habits that are peculiar to a healthy life style, a proper theraphy and a good nursing care, the changeable risk factors can be eliminated; the secondary cases can be avoided or diminished; also the complications that may arise after the disease can be prevented. In this paper our purpose is by using Henderson's Model of Nursing in patients with CVE - to set a pattern which may contribute to overcome the incompetencies of the nurses as to understand the theories and apply them to the care. Besides, the newly acquired knowledge might make a contribution to the nurses' understanding of this group of patients, and through implementing that knowledge -it's hopedsome amount of improvement in the quality of life of patients could be attained.

Keywords: Nursing Care, Cerebrovascular Event, Henderson's Model of Nursing

Corresponding Author: Funda Erol

Address: Sakarya Sağlık Yüksekokulu Esentepe Kampüsü

Adapazarı/SAKARYA., Turkey

Başvuru Tarihi/Received: 23-05-2016

Kabul Tarihi/Accepted: $\quad$ 16-06-2016

E-mail: fundaerol@sakarya.edu.tr

Phone: +90 5075574852 


\section{Giriş}

Her mesleğin geçerliliği, teori üretmek ve uygulamak üzerine temellenir(1). Bu nedenle hemşirelikte uygulamaların bilimsel temele oturtulması önemlidir. Çünkü bir mesleğin bilimsel içeriği, ancak kuram ve kavramlarla ifade edilebilir(2). Hemşirelik kuram ve modelleri, hemşirelere bakım sürecinde rehberlik ederek, güvenli, yüksek kalitede ve hasta merkezli bakım vermelerini sağlar(3). Kaliteli bakım sağlamak günümüzde sağlık bakım hizmetlerinin en önemli hedefidir. Genel olarak hemşireliğin amacı, bireyin sağlığını desteklemek, sürdürmek ya da sağlık düzeyini yükseltmektir. Bunun için hemşireler bakım hizmeti sunarken, hemşirelik teorilerine dayandırımış çeşitli hemşirelik bakım modellerinden yararlanmalıdır(4).

Kavramsal Çerçeve: Henderson'ın
Hemşirelik Modeli

En iyi bilinen hemşirelik kuramcılarından birisi de Virgina Henderson'dır. Henderson, sağlığının korunması ya da yeniden kazandırıması için bütüncül bakım anlayışı ile bireye yardımcı olunması gerektiğini savunmuştur(5). Henderson'un hemşirelik tanımının en büyük kuramsal kaynağı, temel insan gereksinimleridir. Maslow'un temel insan gereksinimleri hiyerarşisini temel alan Henderson, etkili bir hemşirelik bakımı için 14 temel gereksinim belirlemiştir(5,6). Henderson'ın Hemşirelik Modelinde Maslow'un temel insan gereksinimleri hiyerarşisi, hemşirelik bakımını planlarken önceliklerin belirlenmesinde kullanılır(7). Dolayısıyla modelde bu temel gereksinimler, 14 bölüm içinde birleştirilmiştir(6). Bu bölümler Tablo 1'de verilmiştir.

Henderson'un bakım modelini kullanırken hemşire, hastanın bu bileşenlere göre gereksinimlerini değerlendirir(6). Hemşire hastadan gözlem, dinleme, ve hissetme yoluyla verileri toplar, hastanın hemşirelik öyküsünü alır ve hastanın 14 temel gereksiniminden hangisini karşılamakta güçlük çektiğini ve nedenlerini araştırır(2). Henderson modelinde, hemşirenin hastanın gereksinimlerini değerlendirirken yaş, kültürel geçmiş, duygusal denge, bedensel ve zeka kapasitelerini göz önüne alması gerektiğini ifade etmektedir(6). Hemşire topladığı verileri, kuramsal bilgisi ile karşılaştırarak, hastanın mevcut olası sorunlarını belirler(2).

Henderson modelinde hemşirelik bakımının planlanmasının ve bu planların yazılı kayıt altına alınmasının önemini vurgulamaktadır(6). Bakımın planlanması, temel insan gereksinimlerinin karşılanması ve bireyin bağımsızlığını tekrar kazanmasına yardım amacına yönelik yapılır(2). Planın hastanın gereksinimlerine göre sürekli düzenlenmesi gerektiğini de belirtir. Henderson'a göre bakımın planlama aşaması, hastanın gereksinmelerine uygun bir plan yapma, zaman ayarlama, diğerlerinin uygulayabileceği özel plan oluşturma ve hekimin planı ile uygunluğunu sağlamayı içerir(6). Ayrıca Henderson "insanların temel gereksinimleri birbirinin aynıdır, ancak birbirinin aynı olan iki insan yoktur" görüşünü de savunur. $\mathrm{Bu}$ nedenle bakımın bireyselleştirilmiş olması gerektiğine inanır(2).

Henderson hemşirelik uygulamasında bakımın düzenlenmesinin, hemşireliği bir sanat yapan üretken bir öğe olduğu görüşündedir. $\mathrm{Bu}$ üretken bakımın verilmesinde hemşire, hastanın günlük yaşam aktivitelerini elinden geldiğince bağımsız olarak yapmasına yardımcı olur (6). Henderson'un uygulamaya ilişkin diğer önemli görüşü ise, hemşire-hasta ilişkisi ile ilgilidir. Dolayısıyla hemşire, hasta ile empati yaparak hastanın gereksinimlerini belirler ve bakımın niteliğinin hemşirenin bilgi beceri ve yeteneğinden etkilendiğini belirtir. Modelde, 
değerlendirme aşamasında hastanın aktivitelerini bağımsız olarak yapma gücü ve yeteneği üzerinde durulmaktadır. Buna göre, hemşire, hastanın 14 gereksinimini bağımsız olarak karşılayıp karşılayamadığını gözler ve verdiği bakımın sonuçlarını uygun olarak değerlendirir(2).

Serebrovasküler olay (SVO)

İnme veya serebrovasküler olay; serebral damarların emboli ya da serebrovasküler hemoraji ile tıkanması sonucunda iskemiyle neden olan bir tablodur.(8). Serebrovasküler hastalıklar dünyada ve ülkemizde toplum sağlığı için giderek daha fazla önem kazanan hastalık grubunu oluşturmaktadır. Dolayısıyla SVO, tüm dünyada ölüm nedenleri arasında ikinci sıradadır. Gelişmiş ülkelerde de kalıcı sakatlıkların en önemli belirleyicisi olarak kabul edilir(9). Serebrovasküler hastalıklar, ülkemizde de toplam ölümler içinde $\% 15$ sıklığı ile ikinci sırada yer almaktadır(10).

SVO, bireyde birçok nörolojik fonksiyon kayıplarına neden olabileceği için iyi bir gözlem, sürekli değerlendirme ve profesyonel bakım hizmetini gerektiren bir hastalıktır. SVO meydana gelen bir birey; kas iskelet sorunları, yutma güçlüğü, bağırsak ve mesane işlev bozukluğu, bireysel bakımını yerine getirememe ve deri bütünlüğünde bozulma gibi riskler taşımaktadır (11). Dolayısıyla, SVO sonrası bireylerin fonksiyonlarının iyileşmesi, günlük yaşam aktivitelerinin bağımsızlık düzeyinin arttırılabilmesi için hemşirelere önemli sorumluluklar düşmektedir. SVO'lu hastalarda hemşirelik bakımınında; hastalık hakkında özel bilginin artması ve yaşam şekli değişikliğiyle baş etmede hastaya ve ailesine destek verilmesi amaçlanır (8). Sağlıklı yaşam biçimi alışkanlıkları, uygun tedavi ve iyi bir hemşirelik bakımıyla SVO'da değiştirilebilir risk faktörleri elimine edilebilir, sekonder olgular engellenebilir veya azaltılabilir ve hastalık sonrası gelişebilecek komplikasyonlar önlenebilir (12).

Henderson Hemşirelik Modeline Göre Hemşirelik Süreci: Olgunun Profili

Olgunun verileri gerekli açıklamalar yapıldıktan ve sözel olarak izin alındıktan sonra eşinin işbirliği ile toplanmış ve Henderson'un Hemşirelik Modeli'ne göre aşağıda verilmiştir.

\section{Hastanın Tıbbi Öyküsü}

53 yaşında olan bayan A.Ç, emekli öğretmen ve üniversite mezunudur. Evde yakınları tarafından baygın bir şekilde bulunmuş ve hemen hastaneye getirilmiştir. Hastada konuşma bozukluğu, sağ tarafta kuvvet kaybı ve bilinç bulanıklığı fark edilmesi ile çekilen kranial MR'da (bilgisayarlı tomogrofide) sol medial serebral arter alanında infarkt saptanmıştır. Bunun üzerine Nöroloji servisine yatışı yapılan hastaya idrar inkontinansı için foley sonda ve yutma güçlüğü için ise nazogastrik sonda takılmıştır.Ayrıca hasta 20 gün önce el ve ayaklarda karıncalanma tarzında uyuşukluk hissetmiş fakat gün içerisinde hafiflediği için önemsememiş ve bu süre içinde yutmasının giderek güçleştiğini ifade etmiştir. Hastada sigara ve alkol alışkanlığı yoktur.

A.Ç.'nin özgeçmişi değerlendirildiğinde, 2004 yılında hipertansiyon (HT), 2008 yılında da atrial fibrilasyon tanısı aldığı saptanmıştır. Herhangi bir zararlı madde kullanımı (sigara, alkol, uyuşturucu, vb) ve alerji öyküsü olmayan olgunun aile öyküsünde ise annenin hipertansiyon nedeniyle yaşamını yitirdiği belirlenmiştir. Hastanın yaşam bulguları ve nörolojik değerlendirmesi Tablo 2'de verilmiştir. 
Tablo 1. Henderson Hemşirelik Modeli'nin 14 Bileşeni

\begin{tabular}{|c|c|}
\hline Maslow & Henderson \\
\hline $\begin{array}{l}\text { Fiziksel } \\
\text { İhtiyaçlar }\end{array}$ & $\begin{array}{l}\text { 1. Normal solunum } \\
\text { 2. Yeterli yeme içme } \\
\text { 3. Boşaltım } \\
\text { 4. Hareket etme ve uygun pozisyonu } \\
\text { devam ettirme } \\
\text { 5. Uyku ve istirahat } \\
\text { 6. Uygun giyim eşyası seçme, giyinme } \\
\text { soyunma } \\
\text { 7. Çevreye uygun biçimde giyinme ve } \\
\text { beden ısısını normal sınırlarda devam } \\
\text { ettirme } \\
\text { 8. Bedenin temiz tutulması ve cildin } \\
\text { bütünlüğ̈̈n̈̈n korunması }\end{array}$ \\
\hline $\begin{array}{l}\text { Güvenlik } \\
\text { İhtiyaçları }\end{array}$ & $\begin{array}{l}\text { 9.Çevrenin tehlikelerden uzak tutulması ve } \\
\text { kazalardan korunma }\end{array}$ \\
\hline $\begin{array}{l}\text { Sevgi ve Ait } \\
\text { Olma } \\
\text { İhtiyacı }\end{array}$ & $\begin{array}{l}\text { 10.Diğer bireylerle iletişime girerek } \\
\text { duygularını, gereksinimlerini, korku ve } \\
\text { düşüncelerini ifade etme } \\
\text { 11.İnançları doğrultusunda ibadet etme }\end{array}$ \\
\hline $\begin{array}{l}\text { Öz-Saygı } \\
\text { İhtiyacı }\end{array}$ & $\begin{array}{l}\text { 12. Çalışırken başarı duygusuna erişme } \\
\text { 13. Çeşitli eğlence faaliyetlerine katılma } \\
\text { 14.Normal gelişimi ve sağlığı için, mevcut } \\
\text { sağlık olanaklarından yararlanmasına } \\
\text { yardımcı olacak olan öğrenme, keşfetme ve } \\
\text { merakını tatmin etme }(2,6)\end{array}$ \\
\hline
\end{tabular}

\section{Hastanın Hemşirelik Tanılaması}

Yukarıda açıklanan olguda hemşirelik öyküsü alındıktan sonra belirlenen sorunlar, Henderson Hemşirelik Modeli'nde yer alan temel intiyaçlara göre sınıflandırılarak belirlenmiş ve Tablo 3' de verilmiştir.

Henderson Hemşirelik Modeline Göre Olgunun Değerlendirilmesi

Olgunun sorunları belirlendikten sonra, Henderson Hemşirelik Modeline göre olgunun değerlendirmesi Tablo 4 'te verilmiştir.
Tablo 2. Olgunun Yaşam Bulguları ve Nörolojik Değerlendirilmesi

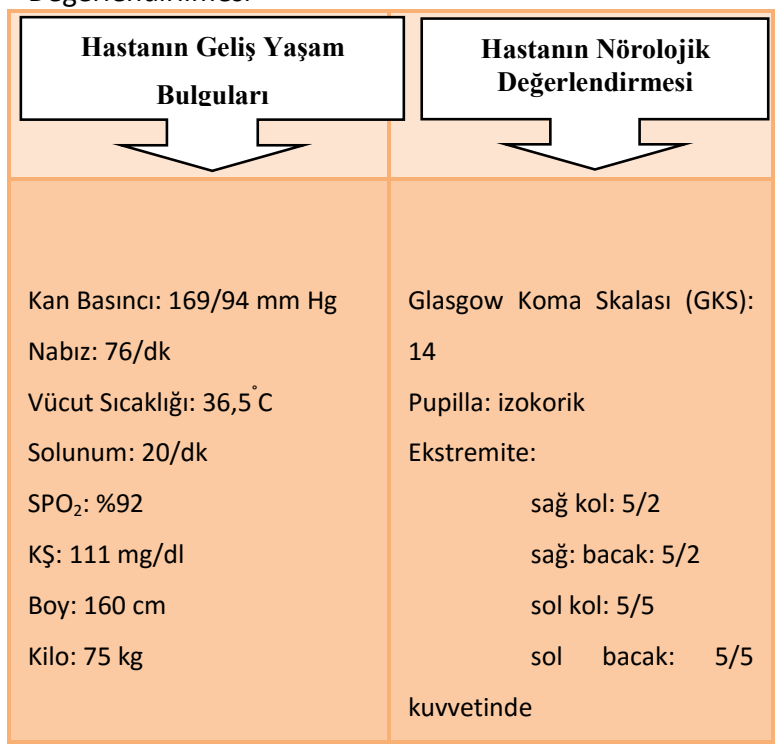

\section{SONUÇ}

Bu makalede, serebrovasküler olay geçiren bir hasta, Herderson Hemşirelik Modeline göre incelenmiştir. Henderson Hemşirelik Modeli; fizyolojik, psikolojik, sosyolojik, sipiritüal ve entellektüel alanda dolayısıyla bütüncül bir bakış açısı ile 14 temel gereksinim üzerine odaklanmıştır. SVO geçiren hastalar temel insan gereksinimlerini karşılayamamaktadır. Bu nedenle, hemşirelik işlevlerinin odak noktası, bireyin kendi kendine gerçekleştiremediği ve hemşirenin yardımını gerektiren gereksinimleri karşılamaktır. Uzun süreli tedavi ve bakım gerektiren en önemli hastalıklardan birisi olan SVO'da bu modelin kullanılmasının hastalığın ortaya çıkardığı ciddi semptomlar azaltılmasında etkili olmakla beraber; uygulanması kolay bir model olduğu düşünülmektedir. Ayrıca hekim istemlerini yerine getirmenin de ötesinde bu model, hemşireliğin özünü yansıtmaktadır. Bu bakım bireylerin bütüncül olarak ele alınmasını sağlayarak, hemşirelere bir çerçeve sunup hasta verilerinin daha kolay toplanmasını dolayısıyla hastanın memnuniyetini ve güvenliğini de arttırmaktadır. Bu nedenle modellerin hemşirelik bakımında 
kullanılmasına yönelik örneklerin arttırılması ve uygulamada kullanımının yaygınlaşması önemlidir. Bu doğrultuda bu modele göre bakımın önemine ilişkin duyarlılığın oluşturulması, kuram-temelli uygulama açısından pilot çalışma grupları oluşturulması, modelleri vakalarla örneklendirerek açıklayan bilim yayınların oluşturulması ve yöneticiler tarafından hasta bakımında Henderson Hemşirelik Modeli'nin kavramsal çerçevesinin kullanılması için uygun şartların sağlanması önerilebilir.

Tablo 3. Henderson Hemşirelik Modeli'ne Göre Belirlenen Sorunların Gruplandırılması

\begin{tabular}{|c|c|c|}
\hline Temel Ihtiyaçlar & Sorunlar & $\begin{array}{c}\text { Belirlenen } \\
\text { Hemşirelik Tanıları }\end{array}$ \\
\hline Normal Solunum & $\begin{array}{l}\text { Hastanın solunumu 28-32/dk. Ara ara dispnesinin } \\
\text { olduğu ve sekresyonunu çıkaramadığı gözlenmiştir. } \mathrm{Bu} \\
\text { durumda hastaya } 21 \mathrm{t} / \mathrm{dk} \mathrm{O} 2 \text { verilmektedir. } \mathrm{SPO}_{2}: \% \\
87(5 . g u ̈ n) \text {. }\end{array}$ & $\begin{array}{l}\text {-Hava yolu açıklığını } \\
\text { sürdürmede yetersizlik. }\end{array}$ \\
\hline Yeterli Yeme ve İçme & $\begin{array}{l}\text { Hastanın disfajisi olduğu için katı gıdaları } \\
\text { yutamamaktadır. Nazogastrik sonda yoluyla jevity } \\
\text { mama başlanmıştır. Tabletleri de suda eritilip } \\
\text { enjektörle verilmektedir. Hastaneye yattığında } 75 \text { kilo } \\
\text { olan hasta } 14 \text { gün içerisinde } 70 \text { kiloya düşmüştür. } \\
\text { Boyu } 1.60 \text { olan hastanın beden kitle indeksi } 27.34 \\
\text { olarak hesaplanmıştır. } \\
\text { Hasta oral beslenemediği için dudakları, kuru ve } \\
\text { çatlak, damakları, soluk, dişlerin görünümü kötüdür. }\end{array}$ & $\begin{array}{l}\text {-Beden } \\
\text { gereksiniminden az } \\
\text { beslenme } \\
\text {-Yutma bozukluğu } \\
\text {-Aspirasyon riski }\end{array}$ \\
\hline Boşaltım & $\begin{array}{l}\text { İdrar inkontinansı olan hasta mesane boşaltımını foley } \\
\text { sonda ile gerçekleştirmektedir. Normalde hergün } \\
\text { defekasyona çıkan hasta, hastanede yattığı } 14 \text { gün } \\
\text { içinde sadece bir defa defekasyona çıkmıştır. Gaitası } \\
\text { ise katı ve şekillidir. Duphalac süs. } 3 \times 2 \text { ölç. } \\
\text { verilmektedir }\end{array}$ & $\begin{array}{l}\text {-Bağırsak boşaltımında } \\
\text { değişiklik } \\
\text { (Konstipasyon) }\end{array}$ \\
\hline $\begin{array}{l}\text { Hareket etme ve uygun } \\
\text { pozisyonu devam ettirme }\end{array}$ & $\begin{array}{l}\text { Hastanın sağ hemiplejisi olduğu için } \\
\text { yürüyememektedir. Kas kuvveti zayıf, sadece sol } \\
\text { kolunu ve ayağını hareket ettirebilmektedir. Günlük } \\
\text { yaşam aktivitelerini yerine getiremediği için eşinden } \\
\text { yardım almakta ve genelde supine pozisyonunda } \\
\text { yatmaktadır. }\end{array}$ & $\begin{array}{l}\text {-Fiziksel harekette } \\
\text { bozulma }\end{array}$ \\
\hline Uyku ve İstirahat & $\begin{array}{l}\text { Genelde uyku problemi olmadığı öğrenilen hastanın, } \\
\text { eşi hastanın geceleri çok fazla uyumadığını, sık sık } \\
\text { uyandığını ifade etmektedir. Hastanın gün içerisinde } \\
\text { uyuduğu ve yorgun olduğu görülmektedir. }\end{array}$ & $\begin{array}{l}\text {-Uyku örüntüsünde } \\
\text { değişim }\end{array}$ \\
\hline $\begin{array}{l}\text { Uygun giyim eşyası seçme, } \\
\text { giyinme soyunma }\end{array}$ & $\begin{array}{l}\text { Hastanın genelde aynı giysileri giydiği, giysilerinin kirli } \\
\text { olduğu ve bu konuda eşinin yardımcı olduğu } \\
\text { görülmektedir. }\end{array}$ & $\begin{array}{l}\text {-Bireysel bakımda } \\
\text { eksiklik }\end{array}$ \\
\hline $\begin{array}{l}\text { Çevreye uygun biçimde } \\
\text { giyinme ve beden ısısını } \\
\text { normal sınırlarda devam } \\
\text { ettirme }\end{array}$ & $\begin{array}{l}\text { Hastanın çevreye uyumsuz giyindiği ve vücut sıcaklığı: } \\
36.2-38.69(5 . \text { gün). arasında seyrettiği görülmektedir. }\end{array}$ & $\begin{array}{l}\text {-Vücut ısısında değişiklik } \\
\text { (Hipertermi) } \\
\text {-Enfeksiyon }\end{array}$ \\
\hline $\begin{array}{l}\text { Bedenin Temiz Tutulması ve } \\
\text { Cildin Bütünlüğünün } \\
\text { Korunması }\end{array}$ & $\begin{array}{l}\text { Hasta hastanede kaldığı } 14 \text { günlük süre içerisinde hiç } \\
\text { banyo yapamamıştır. Hastanın aynı pozisyonda } \\
\text { yatmasına bağlı koksiks bölgesinde ise kızarıklık } \\
\text { mevcuttur. Hastamızın Braden Risk Değerlendirme } \\
\text { Ölçeği toplam puanı:11 (yüksek risk). }\end{array}$ & $\begin{array}{l}\text {-Deri bütünlüğünde } \\
\text { bozulma }\end{array}$ \\
\hline $\begin{array}{l}\text { Çevrenin Tehlikelerden Uzak } \\
\text { Tutulması ve Kazalardan }\end{array}$ & $\begin{array}{l}\text { Hastanın düşme öyküsü sorgulandığında; SVO } \\
\text { geçirdiği andaki düşmesi dışında başka düşme öyküsü }\end{array}$ & -Travma riski \\
\hline
\end{tabular}




\begin{tabular}{|c|c|c|}
\hline Korunma & $\begin{array}{l}\text { olmadıı̆ı öğrenilmiştir. Yatak kenarlarının bazen açık } \\
\text { olduğu görülmektedir. Hasta yürütülmeye çalışılmış } \\
\text { fakat başarılı olunamamıştır. İtaki Düşme Riski" } \\
\text { değerlendirildiğinde toplam skor } 18 \text { (yüksek risk) } \\
\text { olarak hesaplanmıştır. }\end{array}$ & \\
\hline $\begin{array}{l}\text { Diğer Bireylerle İletişime } \\
\text { Girerek Duygularını, } \\
\text { Gereksinimlerini, Korku ve } \\
\text { Düşüncelerini ifade Etme }\end{array}$ & $\begin{array}{l}\text { Hasta söylenenleri anlamakta fakat } \\
\text { konuşamamaktadır. Konuşamadığı ve kendini ifade } \\
\text { edemediği için bazen öfkelenmekte ve ağlamaktadır. } \\
\text { Hasta ile iletişim sözsüz olarak (jest ve mimik) } \\
\text { sağlanmaya çalışılmaktadır. }\end{array}$ & $\begin{array}{l}\text {-Sözel iletişimde } \\
\text { bozulma }\end{array}$ \\
\hline $\begin{array}{l}\text { İnançları Doğrultusunda } \\
\text { İbadet Etme }\end{array}$ & İnançları ile ilgili veri alınamamıştır. & \\
\hline $\begin{array}{l}\text { Çalışırken Başarı Duygusuna } \\
\text { Erişme }\end{array}$ & $\begin{array}{l}\text { Eşi hastanın meslek yaşantısı boyunca çok başarıı } \\
\text { olduğunu, emekli olduktan sonra çeşitli sosyal } \\
\text { projelerde yer aldığııı ifade etmiştir. }\end{array}$ & \\
\hline $\begin{array}{l}\text { Çeşitli Eğlence Faaliyetlerine } \\
\text { Katılma }\end{array}$ & $\begin{array}{l}\text { Eşi hastanın yaşamayı, gezmeyi ve arkadaşları ile vakit } \\
\text { geçirmeyi çok sevdiğini ifade etmektedir. Hasta şuan } \\
\text { yatağa bağımlı olduğu için bu aktivitesini } \\
\text { gerçekleştirememektedir. }\end{array}$ & \\
\hline $\begin{array}{l}\text { Normal Gelişimi Ve Sağlığı } \\
\text { İçin, Mevcut Sağlık } \\
\text { Olanaklarından } \\
\text { Yararlanmasına Yardımcı } \\
\text { Olacak Olan Öğrenme, } \\
\text { Keşfetme ve Merakını Tatmin } \\
\text { Etme }\end{array}$ & $\begin{array}{l}\text { Hasta ile iletişim kurmakta zorlanılması nedeniyle } \\
\text { hastanın bakımı ve hastalığı ile ilgili bilgiler eşine } \\
\text { aktarılmıştır. }\end{array}$ & -Bilgi eksikliği \\
\hline
\end{tabular}

Tablo 4. Henderson Hemşirelik Modeli'ne Göre Hastada Uygulanan Hemşirelik Tanıları, Girişimleri ve

Değerlendirilmesi

\begin{tabular}{|c|c|c|}
\hline $\begin{array}{c}\text { Hemşirelik tanısı/ } \\
\text { Amaç }\end{array}$ & Girişimler & Değerlendirme \\
\hline $\begin{array}{l}\text { Hava yolu açıklığını sürdürmede } \\
\text { yetersizlik. } \\
\text { Amaç: Hava yollarının } \\
\text { açıklığının sağlanması }\end{array}$ & $\begin{array}{ll}\text { - } & \text { Solunum hızı, ritmi, solunum sesleri ve sekresyonun özelliğinin } \\
\text { değerlendirilmesi } \\
\text { - } \\
\text { Düzenli aralıklarla SPO2 takibi yapılması, gerekirse kan gazının } \\
\text { değerlendirilmesi } \\
\text { - Solunum skııntısı belirtilerinin izlenmesi (dispne, siyanoz, yüzeyel } \\
\text { solunum) } \\
\text { - } \quad \text { Hastaya derin solunum ve öksürme egzersizlerinin öğretilmesi } \\
\text { - } \quad \text { Semifowler pozisyonu verilmesi } \\
\text { Pozisyon değişikliklerinde kan basıncı ve intrakraniyal basınç } \\
\text { değişikliklerinin izlenmesi } \\
\text { - Gerekirse hava yollarını aspire edilmesi (aspirasyon işleminin } 15 \mathrm{sn} \\
\text { den fazla sürdürülmemesi) } \\
\text { - } \quad \text { Gerekirse O2 verilmesi (Dr isteminde göre) } \\
\text { Yeterli hidrasyonun sağlanması (IV ve NGS'den) }(2,13,14)\end{array}$ & $\begin{array}{ll}\cdot & \text { Hasta derin solunum ve öksürük } \\
\text { egzersizlerini ögrendi. } \\
\text { - } \\
\text { Solunumu rahatladi, sekresyonunu } \\
\text { çıkarabiliyor. } \\
\text { - } & \text { SPO }_{2}: \% 93-95 \\
& \text { SS: } 16-18 / d k\end{array}$ \\
\hline
\end{tabular}




\begin{tabular}{|c|c|c|}
\hline $\begin{array}{l}\text { Vücut ısısında değişiklik } \\
\text { (Hipertermi) } \\
\text { Amaç:Vücut sıcaklı̆̆ının normal } \\
\text { sınırlarda olması ve hipertermi } \\
\text { belirti ve bulgularının olmaması }\end{array}$ & $\begin{array}{l}\text { - Vücut sıcaklığı ve diğer yaşam bulgularının yakından takip edilmesi } \\
\text { - Ateşi düşürmek için soğuk kompres uygulanması } \\
\text { - Odanın havalandırılması ve giysilerinin inceltilmesi } \\
\text { - Hidrasyonun arttırlması } \\
\text { - Aldığı çıkardığı takibinin yapılması }(2,14)\end{array}$ & $\begin{array}{l}\text { - Hastanın vücut sıcaklığı normal } \\
\text { sinırlara ulaştı. } \\
\left(36.9-37,0^{\circ} \mathrm{C}\right)\end{array}$ \\
\hline $\begin{array}{l}\text { Enfeksiyon } \\
\text { Amaç: Hastanın mevcut } \\
\text { enfeksiyonun iyileşmesini } \\
\text { sağlamak } \\
\text { Hastane yattığı süre içinde } \\
\text { enfeksiyonlardan uzak kalmasını } \\
\text { sağlamak }\end{array}$ & 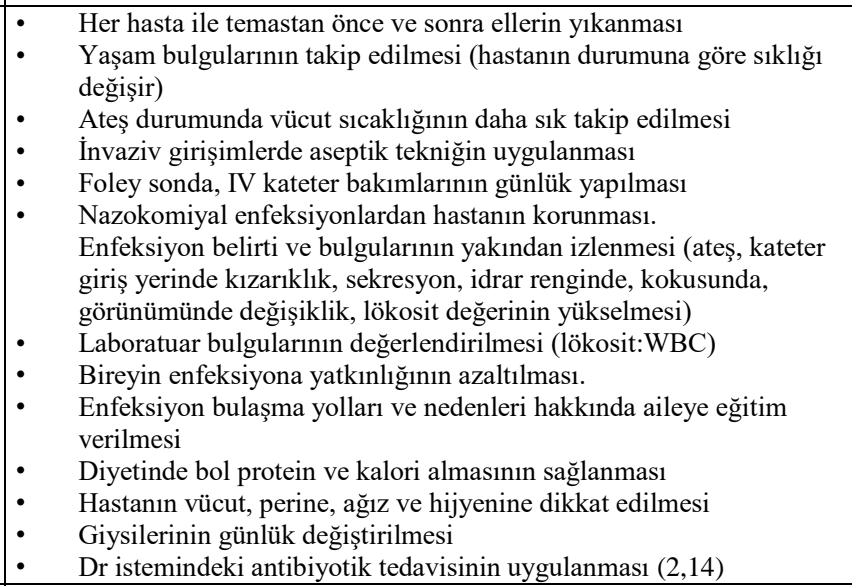 & $\begin{array}{l}\text { - Hastanın sekresyonu azaltılarak } \\
\text { mevcut enfeksiyonunda iyileşme } \\
\text { belirtileri gözlendi. } \\
\text { - WBC: } 8.600 \mathrm{k} / \mathrm{mm} \\
\text { - Hastanede yattığı süre içerisinde } \\
\text { başka enfeksiyona ait belirti ve } \\
\text { bulgular gözlenmedi.. }\end{array}$ \\
\hline $\begin{array}{l}\text { Beden gereksiniminden az } \\
\text { beslenme } \\
\text { Amaç: } \\
\text { Hastanın günlük gereksinimine } \\
\text { uygun beslenmesini sağlamak }\end{array}$ & $\begin{array}{ll} & \text { Bireyin günlük besin ve sıvı alımının değerlendirilmesi } \\
\text { - } & \text { Diyetisyen ile işbirliği yapılarak günlük kalori ve uygun besin } \\
\text { gereksinimi saptanması. } \\
\text { - } \quad \text { Ögünler, yüksek kalorili ve yüksek proteinleri içerecek şekilde } \\
\text { planlanması } \\
\text { - } \quad \text { Labratuar bulgularının takip edilmesi } \\
\text { Hastanın boyu, kilosunun değerlendirilmesi }(2,14)\end{array}$ & 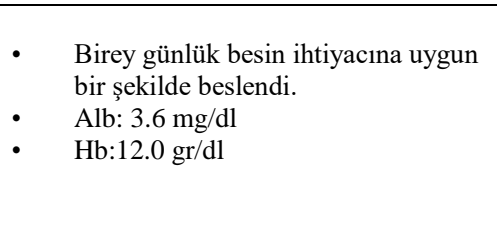 \\
\hline $\begin{array}{l}\text { Oral mukoz memranlarda } \\
\text { değişiklik } \\
\text { Amaç: } \\
\text { Oral mukoz memranların } \\
\text { bütünlügünün ve nemliliğinin } \\
\text { sağlanması ve sürdürülmesini } \\
\text { sağlamak }\end{array}$ & $\begin{array}{ll}\text { - } & \text { Ağız değerlendirilirken ellerin özenle yıkanması } \\
\text { - } & \text { Ağız tanılamasının yapılıası } \\
\text { - Ağı memranın nemliliğinini ve temizliğini sağlamak için hangi } \\
\text { sıklıkta ve hangi yöntemle ağız bakımı verileceğine karar verilmesi } \\
\text { - } \quad \text { Ağız temizliğinde alkollü ve limonlu ajanlar kullanılmaması } \\
\text { - } & \text { Dudaklara yumuşatıcı sürülmesi } \\
& \text { Beslenmesi ve sıvı alımının yakından izlenmesi }(2,14)\end{array}$ & $\begin{array}{l}\text { - Ağız hijyeni sağlanarak oral mukoz } \\
\text { membranlarının bütünlüğü ve } \\
\text { nemliliği sağlandı. }\end{array}$ \\
\hline $\begin{array}{l}\text { Yutma bozukluğu } \\
\text { Amaç: } \\
\text { Seçilen besinleri boğulma belirtisi } \\
\text { olmadan yutabilmesini sağlamak }\end{array}$ & $\begin{array}{l}\text { - } \begin{array}{l}\text { Hastanın yutma durumu ve yutma kapasitesinin gözlenerek } \\
\text { değerlendirilmesi }\end{array} \\
\text { Beslenmeye başlamadan önce, bireyin uyanıklık ve tepki verme } \\
\text { düzeyi, ağız kontrolü, öksürme ve ögürme refleksi ve kendi } \\
\text { tükürügüü̈ü yutma durumunun değerlendirilmesi } \\
\text { - Aspiratör ve gerekli araç-gerecin kolay ulaşılabilir bir yerde ve } \\
\text { çalışır durumda hazır bulundurulması } \\
\text { - Hastaya dik pozisyon verilmesi } \\
\text { - Yemekten 10-15 dakika önce ve sonra bu pozisyonda kalmasının } \\
\text { sağlanması } \\
\text { Özefagusun açıklığını sağlamak için başın, orta hatta } 45 \text { derece } \\
\text { kadar öne eğilmesi } \\
\text { Beslenme planın yapılması ve hastanın istirahatine göre yapılması } \\
\text { Beslenme sırasında hastanın yorulma durumunun gözlenmesi ve } \\
\text { beslenmeye ara verilmesi } \\
\text { Beslenmeye önce muz patates püresi gibi kstı besinelerle başlanması } \\
\text { sonra sıvı besinlere geçme planın yapılması } \\
\text { Hastanın ağżnda sekresyon birikimi varsa yemek öncesi ve sonra } \\
\text { temizlenmesi }(2,14)\end{array}$ & $\begin{array}{l}\text { - Hasta, uygun besinleri aspirasyon } \\
\text { belirtisi görülmeden yutabildi. }\end{array}$ \\
\hline $\begin{array}{l}\text { Bağırsak boşaltımında değişiklik } \\
\text { (Konstipasyon) } \\
\text { Amaç: } \\
\text { Hastanın normal } \\
\text { sıklıkta ve kıvamda } \\
\text { gaita yapmasını } \\
\text { sağlamak. }\end{array}$ & 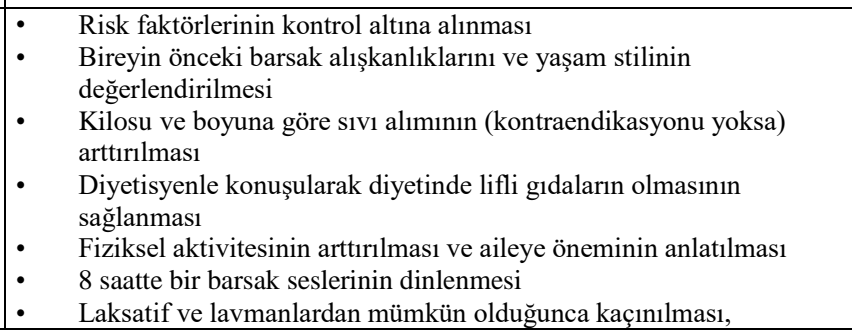 & $\begin{array}{l}\text { - Hastanın gaita çıkışı lavman aracılığı } \\
\text { ile sağlandı. }\end{array}$ \\
\hline
\end{tabular}




\begin{tabular}{|c|c|c|}
\hline & $\begin{array}{ll} & \text { gerektiğinde kullanılması } \\
\text {. } & \text { Barsak eğitim programı hazırlanması ve uygulanması }(2,14)\end{array}$ & \\
\hline $\begin{array}{l}\text { Uyku örüntüsünde değişim } \\
\text { Amaç: } \\
\text { Hastanın yeterince uyumasını ve } \\
\text { dinlenmesini sağlamak }\end{array}$ & 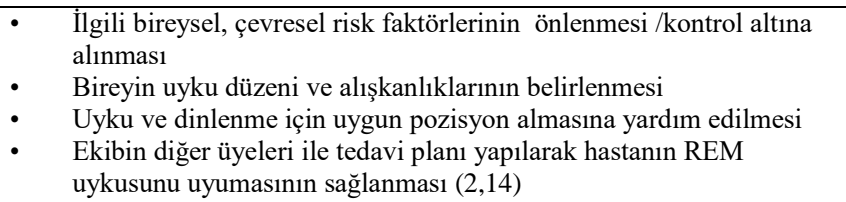 & $\begin{array}{l}\text { Hasta geceleri aralıklı olarak } \\
\text { uyanmaya devam ediyor. } \\
\text { Gün içerisinde belirli saatlerde } \\
\text { uyuması devam ediyor. }\end{array}$ \\
\hline $\begin{array}{l}\text { Deri bütünlüğünde bozulma } \\
\text { Amaç: } \\
\text { Oluşan basınç yarasının } \\
\text { iyileşmesi ve vücut bütünlüğünün } \\
\text { devamlllığını sağlamak }\end{array}$ & 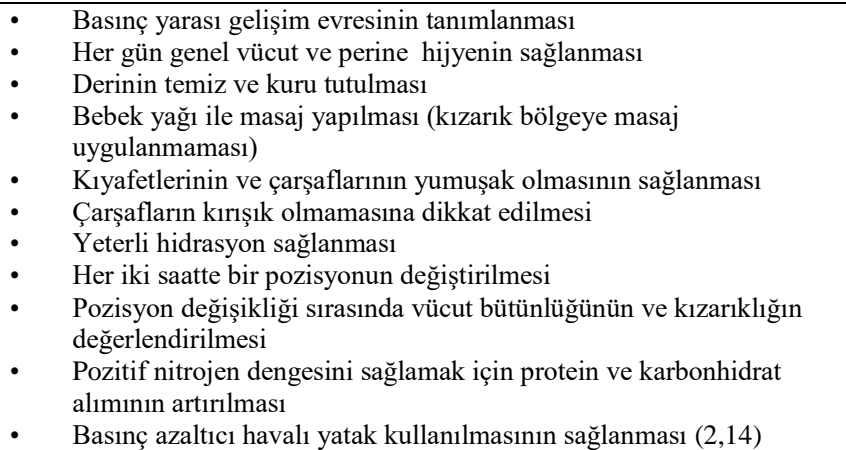 & $\begin{array}{l}\text { - } \quad \text { Basınç yarasında iyileşme gözlendi. } \\
\text { Hastanın koksiksinde bulunan } \\
\text { kızarıklık } 0,5 \mathrm{~cm} \text { küçüldü. }\end{array}$ \\
\hline $\begin{array}{l}\text { Fiziksel harekette bozulma } \\
\text { Amaç: } \\
\text { Hastanın fiziksel hareketlerine ve } \\
\text { egzersizlerine katılımını } \\
\text { sağlamak } \\
\text { Kas iskelet sisteminin normal } \\
\text { fonksiyonlarının devamının } \\
\text { sağlanması }\end{array}$ & 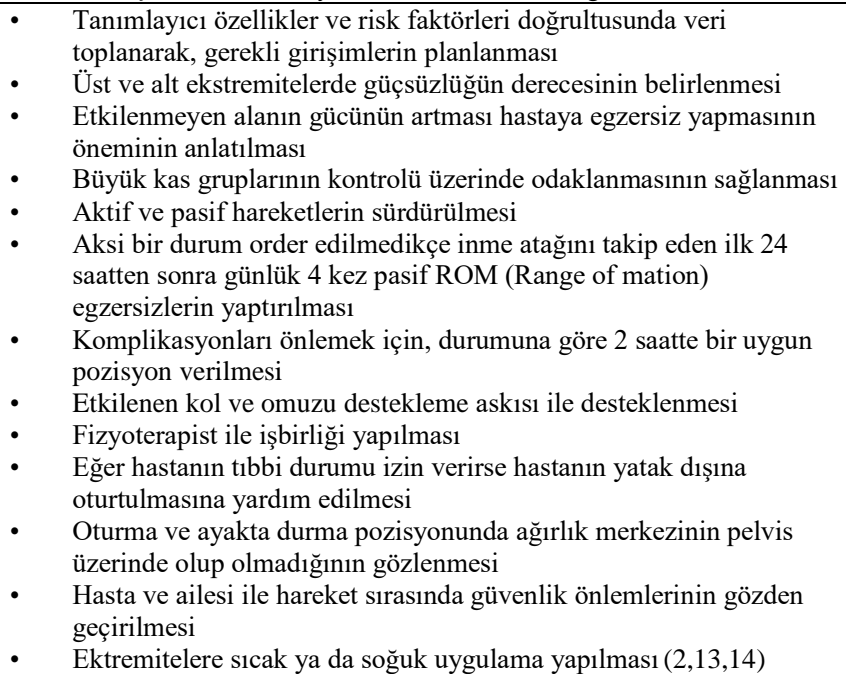 & $\begin{array}{l}\text { - Hastanın yatak içi hareketlerinde } \\
\text { artış gözlendi ve ROM } \\
\text { egzersizlerine katıldı. } \\
\text { - Hasta yürütülemedi. }\end{array}$ \\
\hline $\begin{array}{l}\text { Bireysel bakımda eksiklik } \\
\text { Amaç: } \\
\text { Hastanın sınırlılıkları içinde } \\
\text { özbakım gereksinimlerini yerine } \\
\text { getirmesini sağlamak }\end{array}$ & 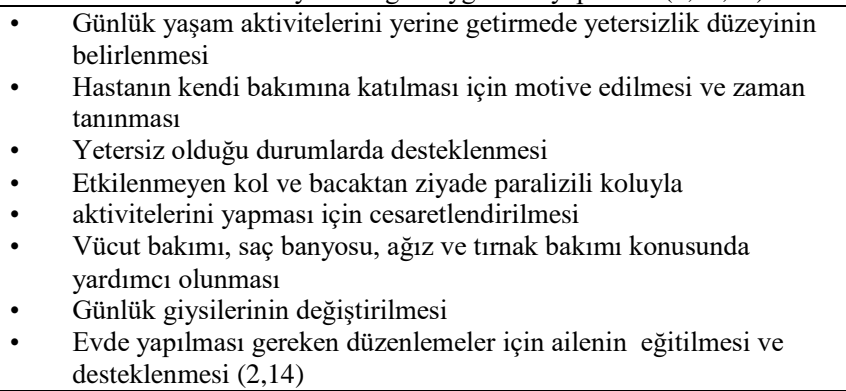 & $\begin{array}{ll}\text { - Hasta silme banyo ve diğer hijyen } \\
\text { gereksinimleri ile rahatlatıldı. } \\
\text { - Hasta giyinme-soyunma işlemlerine } \\
\text { katıldı. }\end{array}$ \\
\hline
\end{tabular}




\begin{tabular}{|c|c|c|}
\hline $\begin{array}{l}\text { Bilgi eksikliği } \\
\text { Amaç: } \\
\text { Hasta ve ailesinin } \\
\text { hastalık sürecini } \\
\text { anlamasını sağlamak }\end{array}$ & 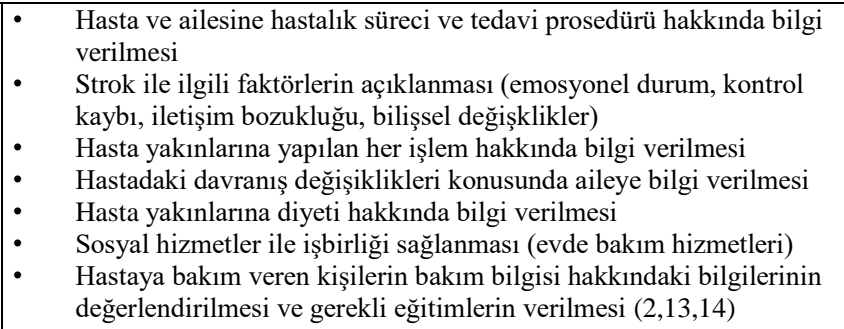 & $\begin{array}{l}\text { Hasta ve ailesinin bilgi eksikliği } \\
\text { giderildi. Hasta başıyla onaylayarak } \\
\text { anlattıklarımızı anladığını belirtti. } \\
\text { Ailesi sorular sorarak eğitime etkin } \\
\text { olarak katıldılar. }\end{array}$ \\
\hline $\begin{array}{l}\text { Sözel iletişimde bozulma } \\
\text { Amaç: } \\
\text { Hastanın etkin iletişim kurmasını } \\
\text { sağlamak }\end{array}$ & $\begin{array}{ll}\text { - } & \text { Hastanın konuşma, anlama, yazma ve okuma yeteneğinin } \\
\text { - } & \text { değerlendirilmesi } \\
& \text { Hasta ile konuşurken yüzüne bakarak basit, açık ve kısa cümleler } \\
\text { - } & \text { Iullanılması } \\
\text { - } & \text { Getişimi geliştirmek için dokunma ve hareketlerin kullanılması } \\
\text { - } & \text { Anlatılanları̈l anlamlerin önlenmesi } \\
\text { - } & \text { Gerektiğinde iletişim için yabi görünüyorsa materyal kullanılması } \\
\text { - } & \text { Konuşma terapisti ile işbirliği yapılması } \\
\text { - } & \text { Ailenin iletişim konusunda desteklenmesi, afazi konusunda bilgi } \\
& \text { verilmesi ve iletişim metotlarının öğretilmesi }(2,14)\end{array}$ & $\begin{array}{l}\text { - Hastanın afazisi devam ediyor fakat } \\
\text { sözsüz iletişim aracılığı ile bakımına } \\
\text { katılması sağlandı. }\end{array}$ \\
\hline $\begin{array}{l}\text { Aspirasyon riski } \\
\text { Amaç: } \\
\text { Aspirasyon gelişmesini önlemek }\end{array}$ & $\begin{array}{ll}\text { - } & \text { S1k ağız bakımı verilmesi } \\
\text { - } & \text { Sekresyonların atılımını kolaylaştırmak için iki saatte bir pozisyon } \\
\text { - } & \text { Herilmesi } \\
\text { - } & \text { Her pozisyon değişikliğinde sırt masajı yapılması } \\
\text { - } & \text { Geslentiğinde orofarengial aspirasyon yapılması anında ve beslenmeden sonraki bir saat süresinde hastanın } \\
\text { başının } 45 \text { derece yüksekte tutulması } \\
\text { - } \quad \text { NGS açıklığı ve yerinde olup olmadığının kontrol edilmesi (mide } \\
\text { - } \quad \text { içeriği aspire edilerek kontrol edilebilir) } \\
\text { Beslenmeden önce rezidüel volümün kontrol edilmesi (eğer rezidüel } \\
\text { içerik saatlik hızın \%10-20'sinden fazla değilse besin verilir) }\end{array}$ & $\begin{array}{l}\text { - Enteral beslenmeye bağlı aspirasyon } \\
\text { gelişmedi. }\end{array}$ \\
\hline $\begin{array}{l}\text { Travma riski } \\
\text { Amaç:Hastanın travmaya maruz } \\
\text { kalmasını engellemek }\end{array}$ & $\begin{array}{l}\text { - } \begin{array}{l}\text { Hastanın hastaneye oryante edilmesi ve yardım çağırma } \\
\text { - }\end{array} \text { Sistemlerinin açıllanması } \\
\text { Yatağın alçak düzeyde ve kenarlıklarının kaldırılmış olmasının } \\
\text { - } \quad \text { Gağlaması } \\
\text { Geceleri yardım isteme konusunda cesaretlendirilmesi ve odanın } \\
\text { geceleride aydınlatılmasının sağlanması } \\
\text { Mobilizasyon öncesi fizik tedavi programının uygulanması ve kas } \\
\text { - } \quad \text { kuvvetinin arttırlması } \\
\text { - } \quad \text { Hastanın mobilizasyonu öncesi yaşam bulgularının ölçülmesi, } \\
\text { - } \quad \text { (yürüteç, koltuk değneği vb) kullanılması azar hareket ettirilmesi, yürümeye yardımcı aletlerin } \\
\text { (yürüyemeyen hastanın önce yatakta oturması, sonra yataktan } \\
\text { sandalye/tekerlekli sandalyeye geçmesi, en son yürümesi sağlanır) } \\
\text { (2,14)) }\end{array}$ & Hastada travma gözlenmedi. \\
\hline
\end{tabular}

\section{KAYNAKLAR}

1- McCrae N. Whither Nursing Models? The value of nursing theory in the context of evidence-based practice and multidisciplinary health care. Journal of Advanced Nursıng 2015; 68(1):222-229.

2-Birol L. Hemşirelik Süreci. 5.Baskı. Etki Matbaacılık Yayıncılık Ltd. Şti: İzmir; 2007.

3-Slatyer S, Coventry L. Twigg DI, Davis S. Professional practice models for nursing: a review of the literature and synthesis of key components. Journal of Nursing Management 2016;24:139-150.

4- Uysal N, Khorshid L, Eşer i. Neuman Sistemler Modeline Göre Bir Vaka Çalışması. Atatürk Üniversitesi Hemşirelik Yüksekokulu Dergisi 2009;12(3):74-81.
5- Ahtisham $\mathrm{Y}$ and Jacoline S. Integrating Nursing Theory and Process into Practice; Virginia's Henderson Need Theory. International Journal of Caring Sciences 2015;8 (2): 443-450.

6-Velioğlu P. Hemşirelikte Kavram ve Kuramlar. Alaş Ofset Matbaacılık: İstanbul; 1999.

7-Atabek Aştı T, Karadağ A. Hemşirelik Esasları. Akademi Basın ve Yayıncılık: İstanbul; 2012.

8- Karakurt P, Kaşıkçı M. İnmeli bir olgunun yaşam modeline göre incelenmesi. Atatürk Üniversitesi Hemşirelik Yüksekokulu Dergisi 2008;11(1):76-84.

9-Irimia $P$, Asenbaum S, Brainin $M$, Chabriat $H$, Martinez-Vila E, Niederkorn K, Schellinger PD, Seitz RJ, Masdeu JC. European Handbook of Neurological 
Management: Blackwell Publishing Ltd: Oxford, UK; 2011.

10-Öztürk, Ş. Serebrovasküler Hastalık Epidemiyolojisi ve Risk Faktörleri- Dünya ve Türkiye Perspektifi. Turkish Journal of Geriatrics 2009;13(1):5158.

11-Karadakovan A. Dahili ve Cerrahi Hastalıklarda Bakım. 2. Baskı. Nobel Kitabevi: Adana; 2011.

12-Bilgili N, Gözüm S. İnmeli Hastaların Evde Bakımı: Bakım Verenler İçin Rehber, DEUHYO ED 2014;7(2):128-150.

13-Albayrak A, Uçak H, Erkal S, Köşgeroğlu N, Ançel G. Nörolojik Bilimler Hemşireliği. Alter Yayıncılık: Ankara; 2006.

14-Erdemir F. Hemşirelik Tanıları El Kitabı. Nobel Matbaacılık: İstanbul; 2012. 